\title{
On the Detention of Aliens: The Impact on Democratic Rights*
}

\author{
MARIE-CLAIRE CALOZ-TSCHOPP \\ Faculté de Psychologie at des Sciences de I'Education, University of Geneva
}

\begin{abstract}
Within the context of the socio-historical framework of globalization, this paper examines how aliens without documents experience democracy in Europe. In order to establish what is at stake, the author examines detention, the threat to human rights and to democracy as a system of government, drawing on empirical evidence as well as philosophical thinking. First the paper identifies the political elements of democracy and how detention-with its attendant deprivation of rights-changes a liberal democracy into a defensive one. The paper then turns to philosophical consideration. It presents an image of society entering a new phase-one of violence engendered by globalization-and challenges us to envisage a reformed political system sensitive to humanitarian needs.
\end{abstract}

\section{Introduction}

\section{The Topic, a Hypothesis and Issues Arising}

Democratic societies are failing to cope with the violence engendered by globalization, progress and unbounded profit. A succession of ecological, humanitarian, technological, economic and political 'catastrophes' support this contention. Confronted with a new era of globally-induced turmoil, democratic structures are fragmenting: the political and institutional frameworks, the goals of democratic societies, and even the image democratic societies have of themselves. In this socio-historical context, aliens are now putting democracy to the test.

With the advent of the nation state, the champions of modern democracy initially cast the Other as a 'non-national' alien (Sayad 1991). This discriminatory categorization commenced the process of the deprivation of political and social rights employed today in immigration and asylum policies, a chain of measures in which detention forms the most disturbing link. Where aliens are concerned, the very framework of the nation state renders even a liberal democracy ineffectual, as Lockak (1985) has explained.

-Translated from the French by Lindsay Hossack 


\section{6}

Marie-Claire Caloz-Tschopp

The trend of excluding millions of people from political participation and denying their rights has been observed in certain 'Southern' countries. But now, in Europe and the northern hemisphere, this trend is taking the form of deterrence, regulation, settlement of populations in designated areas, bogus border closures, and incarceration. The most acute phase of this repression is the use of detention (at present particularly in the UK, Austria and certain East European countries). This is no isolated measure; it forms part of a process. While claiming to adhere to human rights practices, states condemn millions of people-including children-to a condition of 'infra-rights' or 'non-rights', put them behind bars, drive them underground, or confine them to certain areas.

Producing a critique with a view to identifying an alternative policy would entail consideration of denationalization and de-territorialization of rights, which is beyond the scope of this paper (see Caloz-Tschopp 1996a). Rather, this paper considers the detention of aliens without documents, in the context of the right to asylum. Detention calls into question constitutional rights by undermining the sense of security, liberty and equality of those concerned. Quite clearly, detention has a most harmful effect on the liberal state. It follows the sequence of policies of deterrence introduced in Europe in the eighties, initially by Germany; it has been incorporated in the institutionalization of the denial of protected status, in repatriation and forced return. The model of deterrence-in flagrant contradiction of the spirit of the 1951 Geneva Convention-has established itself through by-now well-known means: the ineffectiveness of provision for certain categories of asylum seekers such as women and deserters; the lists of safe countries; visa requirements; the establishment of carrier liability; the creation of registration centres at borders and refugee camps on arrival; the withholding of applicants' rights (freedom of movement, work, support, language tuition, reuniting of families, etc.); and replacing refugee status with temporary protection, thereby leaving the applicants with an undefined status, 'on hold' (Jackson 1995). These measures also call into question the principle of non-refoulement and the clauses governing the suspension of refugee status. They subvert the requirement for a policy of admission and social and economic rights (work, education, health, accommodation, etc.), and a policy concerned with justice-i.e. liberty, safety and non-discrimination.

How might these developments be interpreted and what is their potential impact? Starting from human security in its most basic sense-human beings' right to life, to their own place in the world and hence to action and political allegiance-it is suggested that the chain of measures which includes detention is a significant factor in a process that is changing politics and 'society's image of itself (Castoriadis 1985). It is hypothesised that this is not merely 'another form of government', in which police powers extend their remit and operate in networks (Bigo 1996) under the Schengen Agreement. What can be seen as a sequence of events aptly summed up as 'the police taking the place of the politicians' (Busch 1994), can be termed the passage from a liberal to a 
defensive democracy. These drastic changes, brought about by globalization, should also be seen at a more fundamental philosophical and political level.

Viewed from this perspective, detention, the network of police forces with their differrent measures for security and social control, herald not merely a change in the form of democracy, but are indicators of a changing political regime. A new and unpredictable political system could emerge, with a political apparatus aimed at rather specific objectives entailing the exclusion of some human beings and the transformation of social groups into non-integratable rejects, to be eliminated first from society and then from the world. There are parallels here with other categories of the excluded-what Forrester terms a 'new civilization' in his essay on 'the economic horror' (1996). This also brings to mind Castel's analysis (1995) of the metamorphoses of the social question. In a new order such as this, it would not be completely unforeseen to countenance the emergence of a new form of violence aimed at new enemies who need to be contained, imprisoned-or rather, eliminated. In putting forward this hypothesis we are drawing on Arendt's work on the totalitarian system and the vestiges that remain in the post-totalitarian era in which we now live. It should be recalled that when Arendt defined totalitarianism it was as a completely new political system, unthinkable within the classical categories of political philosophy available to her at the time. Despite this, she was able to portray totalitarianism as a movement of 'total domination', of 'desolation', of limitless violence instrumentalized through technique, destroying everything in its path (human beings and the natural environment). Her analysis then examined the significance and implications for human action, as will be seen later.

The change in political system envisaged here is not, however, a simple return to 'totalitarianism'. What Arendt's work stressed was more the need to heed the event itself, to be aware of the historical discontinuity and to detect the unpredictable. As one significant factor among others, detention would thus no longer be only a sign of the deterioration of a liberal democracy, but an indicator of deeper and more insidious change.

The practical implications of the Schengen Agreement herald such changes. To understand this change we must work from the hypothesis that within globalization, the civilization of violence is escalating. To exercise power by imprisonment and detention is to exercise the right to security as a 'right to punish', in the sense used by Foucault (1975) in his analysis of prisons. Using prison and extending the scope of detention to innocent people is perhaps one step towards exercising a new form of the 'right to wage war' against immigrants and other sectors of the population. A new development is that detention no longer affects only minorities. The rights to freedom of movement, travel, residence, asylum, a salaried job, study, exchange of ideas, association with others, etc., are more and more often grouped, not with life, security, liberty and equality, but with punitive defence, war and death. Taking a negative vision of security such as this, the incarceration of aliens follows on from other forms of punitive deterrence. 
Change is apparent from the fact that the scope for detention has expanded. Fear is being manipulated in new ways-linked not only to the hatred of aliens, but to the survival of humanity in the 'North'. There is also a profound change in society's self-image. Against the fear, indignation and disgust at inhuman treatment of people and what this represents, there is, equally, an attempt to make violence seem natural; the threat to each person's right to life, security and a place in the world becomes conceived as a reality that will become the norm (Amati 1989).

This hypothesis makes new demands on the democratic aim of building a civilization of peace. Fear of the unpredictable is closely linked to obstruction of the processes of thought and of action. The choice, therefore, lies between accepting determinism and being immobile when confronted with developments which question historical wisdom - the social rights whose fragility is now apparent-or joining the struggle for freedom of thought and action by identifying the specific problems.

\section{Detention and Epistemology}

\section{An Overview of European Trends, with Specific Reference to Switzerland}

Detention is one of a set of measures which threaten rights in the Schengen countries of Europe (where there are 13 million citizens of non-EC countries, of whom 6 million are long-term residents). Our locus of reference is limited and examples will be taken primarily from Switzerland.

Switzerland serves as a starting point here because, since the eighties, Switzerland and Germany have been seen to develop a model set of deterrence policies. In 1979 a relatively liberal law on asylum was passed, but this was subsequently subjected to three restrictive amendments. Next came the institutionalized repatriation of aliens, with drastic limits being put on the right to asylum. In addition, there have been repeated violations of fundamental rights in the regulations and in police and administrative practices. These have been denounced on a number of occasions by national and international authorities alarmed at the disappearance of the liberal state in this sector (Swiss non-governmental organizations, the Swiss Parliamentary Business Management Committee (Commission de Gestion du Parlement), the UN, Strasbourg, and recently in relation to the law of restraint, the Federal Tribunal on the law of detention and in several cases of arbitrary detention).

Furthermore, despite being outside the EU, the Swiss authorities with responsibility for immigration and the right to asylum, have shown enthusiasm and imagination by suggesting new measures to the Schengen countries of Europe. These have subsequently been widely applied: for example, the systematic fingerprinting of applicants and the concept of 'safe countries'.

Finally, Switzerland is innovative as regards racist thinking, in introducing what can be termed 'the three-circle model' (Caloz-Tschopp 1996d). It is to be feared that this innovation will spread through the Schengen countries. The 
'three-circle' model for labour recruitment was made public in a Federal Council report on policy relating to aliens and refugees (1991). Since then another Federal Council (FC) text, ironically enough on racism, also makes reference to it (FC 1992). The FC specifies that the model falls within the framework of guiding principles:

The preservation of vital economic and ecological principles, maintenance of a peaceful society and of our national identity, the orientation of state activities towards ethical and humanitarian principles as well as Switzerland's integration into the future Europe are equally premises of future policy regarding aliens and refugees, premises to which all special interests are to be subordinated (FC 1991:30).

These principles, enunciated in Chapter Three, concern the goals and measures 'relating to aliens' (as distinct from asylum policy). The Federal Council imposes two priorities: 'European access' and 'control of the growing migratory pressure from the South to the North and the East to the West', with the objectives of achieving a 'balanced ratio of Swiss to aliens', 'control of migratory pressure' and 'maintenance of the benefits of the economic arena' (FC 1991:12). In order to control access, the FC is imposing a three-tier hierarchy on entry to Switzerland with the right to work, controlled by means of three circles of national identity: the 'inner circle' (EC countries, now the EU and EFTA), whose members enjoy unrestricted access; the 'median circle' (USA, Canada, Japan and, in the future, certain Central and Eastern European countries), with restricted access; and the 'outer circle' (all other states) with no access, apart from rare exceptions.

To sum up, through a policy of limiting unrestricted movement into Switzerland, this model undermines the material bases of social relationships and linkages within which migration takes place. Using the same logic as the fundamental Schengen texts (see Caloz-Tschopp 1991), the model divides the reality of migratory patterns in two, an inside and an outside (the inner and outer circles). It applies entry conditions to the inner circle through selective, hierarchical and unrestricted movement determined by economic needs and Switzerland's domestic and international political choices. By developing a tool for managing immigration in this way, the authorities have created an interventionary tool which physically demarcates the world's economic and political divisions. Migrant workers and refugees, as well as their country of origin, are de facto classified into two areas representing 'North' and 'South' (with a 'median' transit area, for negotiation).

This model, together with newly emerging forms of detention, also leads us to the hypothesis of a changing political system. With the model comes the manipulation of fear by inciting hatred of aliens. With this new racism, fear is manipulated by the state, with one section of the community pitted against the other in the battle for life and survival.

The most recent stage in this type of process is the passing of a law on the detention of aliens without documents. Switzerland has recently passed a law 
on this subject, at a time when European membership, redefinition of the defence policy, the role of the police and the immigration and asylum laws are being debated. On 18 March 1994, the Swiss Federal Assembly passed a federal law on measures of restraint applicable under the law on aliens. The draft bill having been approved by public referendum on 4 December 1994, the new measures came into force on 1 February 1995. For the first time, among other aspects, the law introduced the notion of a preparatory phase of detention (LSEE Art. 13a) and allowed for the maximum period of detention to be extended with a view to repatriation (LSEE Art. 13b). These two measures, according to the law, aim respectively to 'guarantee the implementation of repatriation procedures' (preparatory phase of detention), and to 'guarantee implementation of a decision' (detention with a view to repatriation). Preparatory phase detention has a maximum term of three months; detention with a view to expulsion or repatriation, while not permitted to exceed three months' duration, can however be extended by a further six months maximum. It is possible to detain an alien for twelve months with the sole aim of ensuring his/her repatriation (Künzli, Ackermann 1995:2).

The law lays the foundation for detention and the widening of its ambit (Tafelmacher pers. comm.). It permits imprisonment as well as house arrest and the prohibition of aliens without documents from entering urban areas of Switzerland (LSEE Art. 13b). In this way, as legal opinion has emphasized (Coordination Asile Suisse 1994; Tribunal permanent des peuples 1994), here too Switzerland has taken a pioneering role in repression, which, following Foucault, suggests the extension of the concept of prison to the entire social arena.

\section{Epistemological Comments}

Within the framework of political philosophy, our analytical approach is first of all to consider the phenomena and their global evolution (Caloz-Tschopp 1996c), and to consider detention policy both from general and specific perspectives. In other words, the approach is not to separate the specific policy from its more general relationship to security, war and peace. There are two very simple reasons for adopting this holistic approach. First, when considering the concepts of place of abode, the right to life and security, membership of a community and the right to political freedom, these are just as much a reality as other basic needs (food, work, education, etc.), to the extent that they demand coexistence, or, in simple words, a place in the world for every human being. Second, given the world's current ecological, economic and political organization, 'inside' and 'outside' no longer exist, but rather relationships between social factors exist in 'a continuum of positions coexisting in one entity and which "contaminate" one another' (Castel 1995:442). Far from being an abstract philosophical category, universality has become a physical fact of coexistence and co-dependence. It shows us that society is a dynamic whole and under tension. It is therefore necessary to think in terms of 
the general, not as a diktat of an abstract rationality. It demands that we should not allow ourselves to be hemmed in by specifics (biological life, language, nation, culture, particular ethnic group) and consequently overlook the materiality of social factors as a whole.

The position, therefore, is to take the concept and practice of democracy, not at statis, but undergoing change and tension, and analyse the paradoxes and the contradictions which are exposed within it as it relates to aliens. A starting point is from what Balibar (1992) calls 'the frontiers of democracy' and the conflicts they contain as regards detention.

The perspective is essentially one of political philosophy. Specifically in the present context, a central issue is the task of defining and constructing a political community. Who does it comprise? Who is excluded and on what grounds? What are the conditions for the organization of power as well as analysis of the methods of legitimization, in other words, the ideology that a political community gives itself?

In order to develop this approach, another epistemological choice as regards the status of political thinking is necessary. We need to construct an approach which juxtaposes reason with imagination, emotion, and passion, since all of these elements are at the root of institutions and their conflicts. They are not opposites but complementary ideas, and follow work on rationality by researchers such as Meier-Seethaler (1988, 1996), Feyerabend (1975, 1996), Heller (1981), and Castoriadis $(1985,1992)$. The need to integrate imagination and passion in the process of political thought with ethical evaluations and judgements is an important contention in the context of immigration, asylum and security. Imagination, the emotions and passion are often allied to violent and aggressive actions, as politicians using manipulative practices (e.g. Le Pen in France, Haider in Austria, Blocher in Switzerland) clearly remind us.

In the realm of immigration and the right to asylum, therefore, if we remain confined within a narrow channel of logical thought, we risk overlooking imagination, passion and also fear-all of which are very much present. These are not just important indicators of political change, but of broader changes within a civilization as well. The risk of failing to see these important indicators of change in regime and in the political vision is very real. This kind of epistemological debate and the choice of theoretical perspective is closely linked to an understanding of modern democratic systems, their vision of the future and image of themselves.

The Democratic System, its Future Aims, and the Turbulence of Globalization

\section{The Origins of the Political System and the Democratic Vision}

A brief outline of the theoretical foundations of the democratic vision identifies a number of problem areas in dealing with asylum. In Greco-Occidental culture, democracy originated in ancient Greece. At the outset democracy defined itself as being against oligarchies, and as being the regime 'of the 
greatest number'. In defining itself thus, democracy did not claim to have completed its task and to have achieved a state of stability, but rather saw in itself a potentiality which is never quite attained.

The debate that saw democracy emerge as a political system, a vision of the future, created itself, historically, around the notion of isonomia (equal participation) and meson (centrally held power), paving the way for conflict at the very heart of democracy, as Loraux (1986:246) stresses. The wish for freedom and equality does not rule out the fact that if power were entirely centrally held (through power sharing, rotation of duties and open and nonconflictual debate) and if it were shared in its entirety, the power structure would cease to be. Thus, the representation of a utopia of power-sharing among equals, does not do away with the reality of the conflicts inherent in political life; it is 'one of the vital experiences of civic experience' (Loraux 1986:251). It becomes essential therefore to work on those areas affected by conflict, the frontiers and silences where conflict is the indicator of democratic evolution. The area of policy towards aliens is just such a key area of evaluation.

\section{Democracy as Prisoner of the Civilization of Aggression}

On the one hand the new wave of global turmoil can be regarded as having made a prisoner of the notion and practice of democracy. Alternatively it can be seen as the framework around which to plan for peace. Democracy is a tragic political system containing within itself the potential for both destruction and creation. It is a distinctive political system, self-creating, self-perpetuating and based upon openness rather than restrictiveness (as much in relation to thinking as to borders). It is a political system in which the question of truth, of good, of justice in general 'must be kept permanently open' (Castoriadis 1986:283). It contains, therefore, the need for autonomy, for each human being and society to take responsibility for the unending creation of laws within the political organization and also within the individual's self-limitation, as Castoriadis again emphasizes. In this context, laws about the rights of the individual, such as asylum seekers, lie at the heart of debates about democratic principles and accountability.

In her notes to What is politics? (Qu'est-ce que la politique?) (1996), Arendt too develops the aspects of the gains and potential of ancient democracy. From our point of view, she develops this by radicalizing and opening up political thought. As a counterpoint to totalitarianism, she encourages us to envisage a new form of political system. On the meaning of politics, she writes:

In response to the question of the meaning of politics, there is an answer which is so simple and so conclusive in itself that all other answers seem completely superfluous. And this answer is the following: the meaning of politics is freedom (1996:48). 
Through this affirmation of freedorn she combines the creative and positive foundations of democracy with the meaning defined by the Greeks in the fifth century. Furthermore, she has thought through the problem of rights-the relationship between liberty and equality-starting from Socrates and the notion of isonomia at the origins of Greek democracy.

For Arendt, democratic power is a two-fold evolution. In her description of the totalitarian system (1972), she shows power evolving into the violence of 'total domination', destruction and desolation to the point where it loses its right to be part of the world. When subsequently considering The Human Condition (Condition de l'homme moderne) $(1961,1983)$, she defines power in terms of being the power of human action, of initiative, of a fragile and neverending movement towards the building of a political community which, through this action, entitles it to its place in the world. She further demonstrates that action forms the foundation of what she calls 'the tight to have rights', when she contemplates the fate of the stateless (Caloz-Tschopp 1996b). Conversely, Arendt has given a powerful description of the totalitarian system and how it has taken the deprivation of rights as far as the gas chambers and 'Worldlessness'. Using this approach she goes beyond the contemplation of liberty and equality as simple theoretical or abstract values. Her thinking on liberty and equality is closely tied to the praxis, to the power either to destroy or to act. It is about rights (liberty, equality) being linked to a place in the world for individuals and to rights to life itself. For Arendt these are the bases of a political system which contests absolutely the political system which is inherent in the process of globalization. This is a completely new alternative to totalitarianism and to any post-totalitarian political system bearing the vestiges of totalitarianism (one example of which is defensive democracy; another example is restricting the rights of the 'other'). Or in other words, a new civilization of peace-not aggression-led catastrophe-whose task remains in envisaging and constructing a future in the face of the challenges presented by globalization. Arendt's thinking challenges, therefore, the current approach which democracies are adopting in defining their exclusionary stance towards asylum seekers. It offers a positive outcome for globalization processes, as peaceful and inclusive, not aggressive, exclusive and potentially totalitarian.

\section{One Area of Democratic Conflict: Relating to the Alien}

Arendt's thinking about the tenets of Greek democracy and their relevance to our own times brings us full circle. In the democracy of ancient Greece, the servitude of some guaranteed the freedom of others. We are aware of the inequality between citizen and metic, alien, slave and woman. We know that democracy has never been totally transparent to itself and that 'the polis of the citizens cannot exist without the presence of aliens' (Austin and Vidal-Naquet 1972:118).

This inequality at the heart of democractic structures lies at the core of the contention of this paper. For, one area of dissent and democratic conflict, a 
point from which one can observe the abyss of a civilization based on aggression (which, arguably, characterizes contemporary globalization), is the question whether to open up or close ranks when faced with those designated as the Other. It is this precept which forms the basis that has been established and authorized for the alien being present. Today the issue is not only that more and more rights are being denied the alien, but that undermining these rights could also conceivably threaten not only liberty and equality, but also the right to a place in the world, to life itself. The deaths of people caught up in the system of repression (e.g. prison suicides, death following repatriation, death of returnees) are an indication of this.

The conflict surrounding otherness, a constituent of ancient democracy, has resurfaced and is now impacting on modern democracy. Following the development of a form of racism based on biological criteria (Guillaumin 1972), new forms of racism are seen to be developing around the notion of culture, which is itself turning into a criterion for discrimination, while simultaneously positing an unbridgeable gap between a dominant civilization and the rest of humanity. Thus, the argument for creating a hierarchy of human beings and countries-for example, the Swiss 'three circle' modelbrings us to the question of control and a dilemma that lies at the core of the globalization process: the question of democratic rights and how democracies respond to phenomena which cannot be controlled, such as the alien. This question, Arendt maintains, is central to a progress- and profit-led civilization. In a highly organized civilization which postulates state-endorsed violence in the form of power, progress and limitless profit, the alien-as with any noncontrollable element-creates a disturbance by exposing the limits of globalization and unbounded democracy.

\section{State Power and Physical and Mental Violence}

From the point of view of an analysis based on philosophical and classical political science reasoning, violence is a constituent of the power of the state, with well known arguments for legitimation ranging from Hobbes to Weber. This, again, brings us back to our hypothesis; because new forms of violence, such as imprisoning aliens, and their extension to the social arena, are a form of material and symbolic aggression, which is in part the work of the stateand is now going beyond it (the multinationals, the Mafia, 'civil society'). As far as the state is concerned, in its detention of aliens without documents, acts of physical intervention are material but invisible. They take place behind the scenes. Individuals are arrested. They are deprived of their freedom on explicit administrative grounds and implicit political grounds. They are maltreated, kept in isolation, imprisoned. They are confined in specific locations, then repatriated physically. This is violence in kid gloves. What is the real and symbolic status of this civil practice? In this context, what do restricted movement, arrest, detention, isolation, poor treatment and physical return constitute? With regard to a political system, what interpretation can be put on 
these methods of political domination over the physical bodies of human beings, over subjects with rights who are turned into manipulable objects?

Writing on the beginnings of the prison system, Foucault (1975) has shown that the nineteenth century was delighted with this new gentle approach of chastising the soul rather than the body. With present-day detention, a double evolution is taking place: a reversion to historical practices through a form of violence perpetrated on the body, but which is not visible (no physical evidence), but which, however, is all too real when combined with the chastisement of the soul as identified by Foucault. On the one hand there is a legalized return to the practice of violence against aliens while broadening the notion of detention; on the other, the legitimacy of state violence, accompanying the violence of globalization, is impressed upon the population as a whole. A two-fold violence is thus created and institutionalized: violence to the physical body and to the psyche. Is this a case of directing activity (Haroche 1994) to a new social arena: to bodies and minds in order to establish authoritarianism in the absence of authority? Selecting vulnerable targets-aliens-in order to convey a message to all subjects, opens up the possibility of attacking not only rights and freedom, but also life. Here, then, is the onset of change in a political system.

There is a manifest link between: the art of separating social arenas, pinning down, enclosing, and clandestinely assaulting populations; the art of dominating the minds of all subjects (not only designated victims); and a political system's transition into global violence. Even if this link remains obscure and needs to be further analysed, there can be defined a new complementarity between a physical violence which leaves no mark, the expanded scope of prison, the control of people's consciences and the establishment of a new political regime.

\section{Deprivation of Rights and Freedom-A Form of Torture?}

Studies carried out on the trauma of displaced people usually concern the trauma experienced in the country of origin (Sironi 1992) rather than in the 'host' country where the focus is on the procedures for immigration and asylum. For example, in Switzerland, when poor treatment is instanced, it relates to people held in custody (Amnesty International 1994) and the detention conditions for the prison population in general. In the sphere of the right to asylum, when torture has been reported, it relates to practice in the country of persecution, to the 'risk of torture and implications for safety' in the case of repatriation (UN 1994) or 'in rare cases, ill treatment meted out by Swiss officials'. A case can be made that countries repatriating asylum seekers may be complicitly condemning them to torture. Although there is a link, it is very difficult to demonstrate direct causality between an individual's return and the fact that he or she is arrested or tortured, if not assassinated. At this level the dynamics of causality in establishing responsibility are complex. 


\section{6}

Be that as it may, the generalization of detention and border closures across Europe makes it necessary for us to move away from the issue in relation to the asylum seekers' countries of origin, and to focus on their countries of temporary or clandestine residence as well.

Other studies are beginning to describe the traumas of detention in European prisons. Here, it is striking that descriptions of psychological aggression acknowledged under dictatorships, have spread to situations of detention in European countries. Thus, at an ECRE seminar in Copenhagen in November 1995, echoed by UNHCR (1995), a psychiatrist described the detention of asylum seekers as a new form of 'torture without physical violence'. She explained that detention would last up to five years and that the prisoners displayed symptoms described in terms of the torture under dictatorships (Latin America, Turkey, etc.). How does detention qualify as a new form of torture? It is not possible within the scope of this article to discuss the classification criteria for forms of torture. However, it is not enough to stop at the phenomenological descriptions of detention as torture, which are offered by medicine or social services. This sort of definition is essential when assessing a situation with a view to treating the victims. But at a political level, there are other questions to be asked. It is possible that this psychological shift, experienced not only by victims but even more so by the overall population, through new forms of violence and the deprivation of rights-in this case, detention-accompanies an alteration in the political system, which demarcates entry to a new phase in society's self-image.

When Puget (1989) talks of a connection between state-instigated violence and society, his assertions could be applied-admittedly to a lesser degree-to the relationships between nationals and aliens and perhaps also between nationals as well. State violence instils fear, silence and isolation. There is no place for speech. State-instigated violence severs all contact between detainees and the population as a whole by locating detainees in complete isolation. Furthermore, aliens are increasingly confined away from urban areas, thereby extending the sphere of imprisonment across the entire social arena.

The Political and Philosophical Meaning of the Deprivation of Freedom and Rights

Does the law (Swiss law, in this case) only target aliens without documents? When the law was passed it did have another purpose. "The law gave the impression that the state was taking things in hand and this was sufficient to quieten people down' (von Moos, a Lucerne lawyer, in Hebdo 8.2.96). Clearly, it was a question of the legitimacy of government authority. A comment such as this suggests that the law has a different scope as soon as conflicts arise over the role of the state as a social entity and debate over the strength of identity enjoyed by the state as a political entity. Here the state is not dealing with minor offences or social injustice but something quite different. The law intends to instil fear (Caloz-Tschopp 1993) while indicating a new logic of aggression. 
Incorporated within the overall perspective of globalization, the law aims to impose on the entire population an acceptance of the emerging defensive democracy: a democracy favouring security over liberty, or in other terms, an 'authoritarian social state' (Tafelmacher 1996) along with deregulation of working conditions, statutes and contracts, a lowering of salaries, review of social security, a significant increase in unemployment, a policy of highly selective admission into countries within the Schengen arena, and other factors too.

The law institutionalizes the use of physical violence on aliens, the withdrawal of a whole series of rights, restricted freedom of movement, arrest, detention and repatriation. Having identified the new enemies, the law attempts to eradicate them: dispossessed of their rights by society, they are then turned into detainees or outcasts or even missing persons, thereafter categorized as rejects and disposable. This type of political agenda manifests itself in a broadening of the scope of detention and the construction of new prisons designed to isolate the alien. A demonstration which took place in Zurich is relevant here, in which $\mathbf{5 0 0}$ young people, gathered to shout 'freedom' outside the prison walls, were confronted by 180 policemen. The prison had been effectively sealed to reinforce isolation-through special glazing and walls-so that the detainees would not be able to see or hear the demonstrators' shouts. Thus, violence is apparent in the complete isolation of detainees from the population.

If, for Puget, the physically liquidated 'disappeared' are the symbol of Latin American dictatorships, it could follow that detained aliens in Europe and the northern hemisphere are becoming one of the symbols in social relationships, of a change not only from a liberal to a defensive democracy but also of a change in political system in the sense evoked by Arendt. People subjected to this invisible form of violence by being removed are thereby turned into public enemies. They are representatives of the social and political situation in the world of millions of so-called 'unproductive' people in the wage economy. Their enforced presence prompts the thought that each one of them could be part of the wastage from globalization's new turmoil. It is conceivable that what globalization has done to some could be the fate of any one of us.

\section{By Way of Conclusion: Democracy's Vision of the Future Held in Abeyance}

The debate on the law of restraint has exposed a relatively new area of conflict in the Swiss political system, new in its importance at any rate. The situation is not specific to Switzerland; it appears in several European countries. In the last twenty years an asylum movement made up of ordinary citizens, grass-root trade unionists, political parties, non-governmental organizations and churches has developed. This movement has brought action within the framework of the liberal state, direct democracy and civil disobedience (safe havens, sponsorship of applicants, administrative guerrilla warfare, etc.). Conflict on the theme of 
the right to asylum has been manifest in political and referenda debates and through supportive action and legal challenge.

Apart from the activities of the asylum and anti-racist movements and sections of the Church which are very active in the defence of the right to asylum, the new factor is the entry into the political arena of legal challenge. Legal theorists and practitioners, while continuing to hold objective professional viewpoints, have publicly expressed concern for and disagreement over the judicial processes and the implications of new laws for the rights of aliens and asylum seekers.

In Switzerland there has been opposition of this kind to the majority party who voted in the restraint measures, and to parliament, the executive, the bureaucracy and the police more generally. There was opposition during the debate on the introduction of the law and in particular once implementation of the law had begun. At the time of the debate, the bill was considered by lawyers to call into question basic freedoms (Auer 1994). Moreover, the appropriateness of the use of restraint was also discussed by the lawyers at the highest judicial level in the country: 'In a liberal state, restraint should only be applied as a last resort, not as a preventive measure' (A. Zünd, Clerk of the Federal Tribunal, in Hebdo 8.2.1996, Lausanne). Since the law came into force, excessive use of it has been and continues to be condemned.

Are Swiss lawyers, in the courts and in academia, more aware than other sectors (notably parliament, state institutions and the electorate) that a defensive democracy is being created? It may well be that lawyers' professional attention to the principles and criteria of the liberal state makes them more conscious of the political issues when it comes to the creation of a defensive democracy. This awareness is important. But it is also important to set it alongside the generalized fear within the population, which is not so much a hatred of the foreigner and racism, though these exist, as a widespread fear of the unpredictable changes present behind the law of restraint and the model of the three circles. Directing questioning in this way would help detect and aid consideration of the unpredictable.

Perspectives like this are important for citizenship. They suggest new ways of building a democratic vision by considering universality, co-dependence, and movement beyond national boundaries erected like so many new dividing lines. Hopefully, they offer a perception of democracy elaborated by Arendt, as a civilization of peace where the right to life and security are the rights on which all rights are founded, and where the political process is never complete.

AMATI, S. (1989) 'Récuperer la honte', pp. 105-121 in Puget, J. et al. Violence d'Erat if psychanalyse, Paris: Dunod.

AMNESTY INTERNATIONAL (1994) Suisse. Allégations de maurais traitements pendant lu gard. $d$ vue, London. Doc. II/7.

ARENDT, H. (1972) Les origines du tolalitarisme. Paris: Points-poche. (English onginal: Th: Origins of Toralitarianism, 3rd. edn. London: Deutsch. 1986.)

- - (1961, 1983) Condition de l'homme moderne. Paris: Calmann-Lévy. (English origınal: Thk' Human Condition. Chicago: University of Chicago Press. 1958).

- (1996) Qu'est-ce que la politigue? Paris: Seuil. 
AUER, A. (1994) La constitution fédérale, les droits de l'honume et les mesures de contrainte à l'ègard des cirrangers, Geneva: Université de Genéve.

AUSTIN, M. and VIDAL-NAQUET, P. (1972) Économies et soclétés en Gréce anclenne, Paris: Colin.

BALIBAR, E. (1992) Les frontières de la democratie, Paris: La Decouverte.

BIGO, D. (1996) 'Sécurité, immigration et contrôle social. L'archipel des polices', Le Monde diplomatique, 9 October.

BUSCH, N. (1994) 'Police ou politique? pp. 391-407 in Caloz-Tschopp, M. C., Clévenot, A. and Tschopp. M.-P. (eds.) Asile-Violence-Exclusion en Europe. Histoire, analyse, prospective, Geneva: Cahiers de la Section des Sciences de l'Éducation de l'Université de Genève et Groupe de Genive 'Violence et droit d'asile en Europe'.

CALOZ-TSCHOPP, M. C. (1991) 'La Suisse, terre de refoulement(s)', pp. 414-428 in Masnata, F. and Rubattel, C. (eds.) Le pouvoir subse 1291-1991, Lausanne: éd. de l'Aire.

- - (1993) 'A propos de sécurité intérieure: le rêve d'une démocratie sécuritaire et la manipulation de l'angoisse', pp. 193-218 in Coordination Asile Suisse, Mouvement pour une Suisse ouverte, democratique et solidaire, SOS-ASILE VAUD Europe! Montrez patte blanche! Les nouvelles frontières du laboratoire Schengen, Geneva: CETIM.

- - (1996a) 'La création de la démocratie et de l'asile par l'action politique contre le néolibiralisme sécuritaire', in Carlier, J. Y. (ed.) L'Europe et les réfuglés, Bruxelles: de Boeck.

- - (1996b) 'Les sans Etat dans la philosophie politique de Hannah Arendt. Privation du politique, de la pensée ou appartenance et action politique' (thesis). Paris: Institut d'Etudes Politiques.

- - (1996c) Une philosophie du mourement ou du pouroir en tant qu'action/Eine politische Philosophie der Bewegung. Die Grundbedingung für Handeln, Olten: Frauenrat.

- - (1996d) "A propos du "modèle des trois cercles". Le racisme institutionnel et l'emprisonnement du pouvoir de penser et d'agir', Zurich: Widerspruch 32: 151-162 (German text); Paris: Transeuropeienne 9: $31-41$ (French text).

CASTEL, R. (1995) Les métamorphoses de la question sociale, Paris: Fayard.

CASTORIADIS, C. (1985) L'institution imaginaire de la sociête, Paris: Seuil.

- (1986) 'La polis grecque et la création de la démocratie', pp. 261-307 in Domaines de l'homme, Paris: Seuil.

- - (1992) 'Passion et connaissance', Diogène 160: 78-98.

COORDINATION ASILE SUISSE (1994) Rapport sur les infractions imputees a la Suisse en maticie d'asile pour la période 1979-1994 déposé dans le cadre de l'accusation a la séance sur le droit d'asile de Tribunal Permanent des Peuples, Berlin, December.

FEYERABEND, P. (1975) Against Method: Outline of an Anarchic Theory of Knowledge, NLB; Humanities Press.

- (1996) Mirec Dialogues on Knowledge, Oxford: Blackwell.

FEDERAL COUNCIL (Conseil fédéral) (1991) Rapport du Consell fédéral sur la politique à l'égard des étrangers at des réfugiés du is mai 1991, Berne (no. 91.036).

- - (1992) Message concernant ladhésion de la Suisse à la Conrention international de 1965 sur l'ílimination de coutes les formes de discrimination raciale et la ré vision y' relative du droit pénal du 2 mar. 1992. Berne (no. 92.029).

FORRESTER, V. (1996) Liorreur économique, Paris: Fayard.

FOUCAULT, M. (1975) Surveiller et punir, Paris, Gallimard.

GUILLAUMiIN, C. (1972) L'idéologie raciste. Genèse et langage actuel, Paris: Mouton.

HAROCHE, C. (1994) 'Le gouvernement des conduites', Paris, Magazine littéraire 325:40-45.

HELLER, A. (19S1) Theorie der Gefühle, Hamburg: VSA-Verlag.

JACKSON, I. (1995) 'Plaidoyer pour une ouverture'. Geneva, Vivre Ensemble 54: 13-16.

KÜNZLI, J. and ACKERMIANN, B. (1995) Avis de droit. Sur les régimes de délention en phae priparatoire el en vue du refoulement, Berne: OSAR.

LOCKAK, D. (1985) Ėtrangers: de quel droit? Paris: PUF.

LORAUX, N. (1986) 'Repolitiser la cité', L'Homme 97/98: 239-255.

MEIER-SEETHALER, C. (1988) Urspriüge und Befreiungen: Eine dissidente Kulturtheorie, Zurich: Arche Verlage.

- - (1996) 'Healing the Cleavage: Emotional Reason as Source of Universals', pp. 125-130 in Berthoud, G. and Sitter-Liver, B., The Responsible Scholar: Ethical Considerations in the Humumties and Social Sciences, Canton, USA: Watson Publishing International.

PUGET, J. et al. (1989) Violence d'Élat et psychanaly'se, Paris: Dunod. 


\section{Marie-Claire Caloz-Tschopp}

SAYAD, A. (1991) L'immigration ou les paradoxes de l'altérité, Bruxelles, De Boeck.

SIRONI, F. (1992) 'Les victimes de tortures et de répression: Nature, singularité et fonction du traumatisme', Psychologie médicale 24(5): 459-464.

TAFELMACHER, C. (1996) Asstgnation, armée, arrêtés fédéraur urgents: émergence d'un État social autoritaire, Geneva: Groupe de Genève 'Violence et droit d'asile en Europe'.

TRIBUNAL PERMANENT DES PEUPLES (1994) Session sur le droit d'asile en Europe. Sentenc' prononcée le 12.12.1994 à Berlin, Rathaus Schonberg, Rome: Basso-Tribunal.

UN (1994) Convention contre la torture et autres peines ou traitements cruels, inhumains ou dégradants: Examen des rapports présentés par les Etats parties en vertu de l'article 19 de la Convention (Suisse) du 24.9.1993, 2. CAT/C/17/Add.12.Doc.II/32.

UNHCR (1995) Delention of Asylum-Seekers in Europe 1(4), Geneva.

Hebdo is a weekly published in Lausanne.

LSEE (Loi sur ke séjour et Tétablissement des étrangers) is the Swiss law on right of abode of aliens, currently undergoing revision.

MS received June 1996; revised MS receired November 1996. 